\title{
A review on important maize diseases and their management in Nepal
}

Subash Subedi*

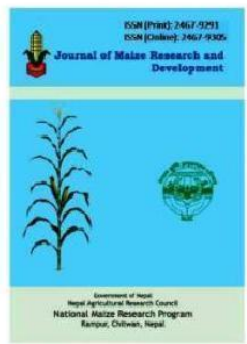

\section{ARTICLE INFO}

Article history:

Received:

$5{ }^{\text {th }}$ September, 2015

Revised :

$25^{\text {th }}$ October,2015

Accepted:

$10^{\text {th }}$ November, 2015

Keywords:

Maize, disease, control/ management

\begin{abstract}
In Nepal, maize ranks second after rice both in area and production. In recent years, maize area and production has shown a steady increase, but productivity has been low (2.46 t/ha). The major maize producing regions in Nepal are mid hill $(72.85 \%)$, terai $(17.36 \%)$ and high hill $(9.79 \%)$ respectively. A literature review was carried out to explore major maize diseases and their management in Nepal. The omnipresent incidence of diseases at the pre harvest stage has been an important bottleneck in increasing production. Till now, a total of 78 (75 fungal and 3 bacterial) species are pathogenic to maize crop in Nepal. The major and economically important maize diseases reported are Gray leaf spot, Northern leaf blight, Southern leaf Blight, Banded leaf and sheath blight, Ear rot, Stalk rot, Head smut, Common rust, Downy mildew and Brown spot. Information on bacterial and virus diseases, nematodes and yield loss assessment is also given. Description of the major maize diseases, their causal organisms, distribution, time and intensity of disease incidence, symptoms, survival, spreads, environmental factors for disease development, yield losses and various disease management strategies corresponded to important maize diseases of Nepal are gathered and compiled thoroughly from the available publications. Concerted efforts of NARC commodity programs, divisions, ARS and RARS involving research on maize pathology and their important outcomes are mentioned. The use of disease management methods focused on host resistance has also been highlighted.
\end{abstract}

\section{INTRODUCTION}

Plant diseases are of paramount importance to humans because they damage plants and plant products on which humans depends for food, clothing, furniture, the environment and in many cases the housing. The kinds and amounts of losses caused by plant diseases vary with the plant or plant products, the pathogen, the locality, the environment, the control measures practiced and combination of these factors (Agrios, 2005). Disease is one of the major biotic constraints to reduce crop yield and also deteriorate the quality of product that ultimately reduce the market price. The reason behind the low productivity of most of the crops in Nepal is due to the attack of many

Corresponding author Info:

*Scientist/Plant Pathologist

National Maize Research Program, Rampur,

Chitwan Nepal Agricultural Research Council

(NARC) Phone: 977-9845066695

E-mail: subedi.subash1@gmail.com 
plant diseases at different stages of crop. Maize is a most important cereal crop in Nepal and also the principal staple cereal diet of most of the Nepalese people who mainly lives in hilly region. Maize contributed $24.93 \%$ in total edible cereal grain production in Nepal. The total area under maize production is 928,761 ha in Nepal where mid hill, terai and high hill occupies 72.85, 17.36 and 9.79\% respectively (MOAD, 2014). The national average yield of maize is $2.46 \mathrm{mt} / \mathrm{ha}$ which is quite low compared to neighboring countries. The Nepalese maize yield level at present is far below than potential yield. There is a wide gap between potential yield of maize varieties having $6.7 \mathrm{t} / \mathrm{ha}$ (on-station experimental yield), attainable yield of about $5.7 \mathrm{t} / \mathrm{ha}$ (on farm yield with improved practices) and national yield of $2.4 \mathrm{t} / \mathrm{ha}$ (Figure 1) (NMRP, 2014). There are various biotic and abiotic yield limiting factors in maize of which diseases and poor crop management are important ones. Maize plants are affected by wide range of pathogens with fungal and bacterial diseases being the most important in Nepal.

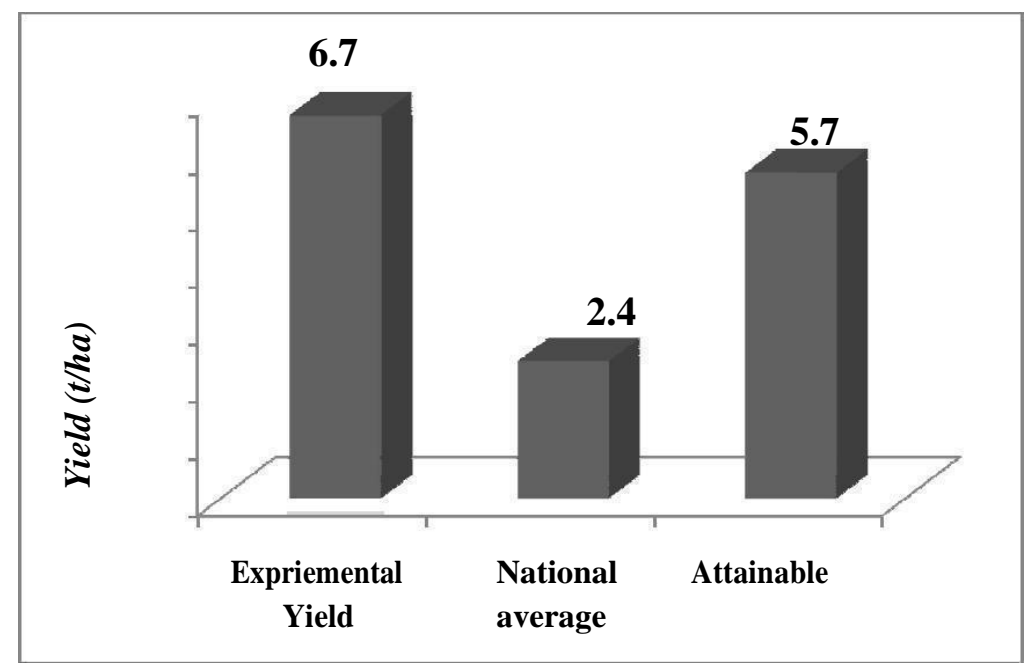

Figure 1. Yield gap of maize in Nepal

Maize is susceptible to many fungal pathogens, to a lesser no of pathogenic bacteria, nematodes and viruses, to least one mycoplasma like organisms and one parasitic like higher plant. Seventy-five fungal and three bacterial species have been recorded pathogenic to maize crop in Nepal (Manandhar, 1997). Several of them are economically important. Besides several nematode species were isolated that are known to be pathogenic in maize (Manandhar, 1997). Some virus diseases have been suspected but have not been verified in Nepal (Manandhar, 1983). Important maize diseases and their status in different agro-ecological regions are presented in Table 1. Maize disease investigation was initiated in 1964-65 when there was not one improved variety of maize in the country (Manadhar, 1983). The preliminary investigation of maize diseases was initiated along with a general plant disease survey by the Plant Pathology Division, Khumaltar (Khadka and Sah, 1967). Among the diseases recorded, only a few are economically important. The major diseases have been primarily managed by the development of the resistant varieties. This paper focused on major maize diseases which are considered serious constraints to productivity and production of maize in Nepal. 
Table 1. List of maize diseases and their first record of prevalence (Year/Location) and status in Nepal

\begin{tabular}{|c|c|c|c|c|c|}
\hline \multicolumn{2}{|r|}{ Disease } & \multirow[t]{2}{*}{ Pathogen } & \multirow{2}{*}{$\begin{array}{c}\text { First Record of disease } \\
\text { prevalence (Year / Location) }\end{array}$} & \multicolumn{2}{|c|}{ Status } \\
\hline & & & & $\begin{array}{l}\text { Terai and } \\
\text { inner } \\
\text { Terai }\end{array}$ & $\begin{array}{c}\text { Hills/high } \\
\text { hills }\end{array}$ \\
\hline \multicolumn{6}{|c|}{ Fungal Diseases } \\
\hline \multicolumn{6}{|l|}{ Foliar } \\
\hline 1. & Gray leaf Spot & Cercospora zeae maydis Tehon \& Daniels & $\begin{array}{l}\text { 2006/ Dhungkharka, } \\
\text { Kavrepalanchowk }\end{array}$ & Minor & Major \\
\hline 2. & Northern leaf blight & Helminthosporium turcicum Pass & 1964/ Patan & Minor & Major \\
\hline 3. & Southern leaf blight & Helminthosporium maydis Nisik and Miyabe & 1965/ Rampur & Major & Minor \\
\hline 4. & Banded leaf and Sheath Blight & Rhizoctonia solani (Kuhn) & 1978/Rampur & Major & Major \\
\hline 5. & Common rust & Puccinia sorghi Schw. & 1964/ Patan & Minor & Major \\
\hline 6. & Brown spot & Physoderma maydis Miyabe & 1965/Gokarna & Minor & Major \\
\hline 7. & Leptosphaeria leaf blight & $\begin{array}{ll}\text { a. } & \text { Leptosphaeria zeae Stout } \\
\text { b. } & \text { Leptosphaeria michotii (West) Saco }\end{array}$ & 1965/Ilam & Minor & Major \\
\hline 8. & Curvularia leaf spot & $\begin{array}{ll}\text { a. } & \text { Curvularia lunata (Walker) Boedjn } \\
\text { b. } & \text { C. geniculata (Tracy and Sarle) Boedjn } \\
\text { c. } & \text { C. pallescens Boedjn } \\
\text { d. } & \text { C. leonensis M.B. Ellis }\end{array}$ & $\begin{array}{l}\text { 1966/Kakani } \\
\text { 1966/Godawari } \\
\text { 1966/Kakani } \\
\text { 1967 /Kakan } \\
\text { 1974/Rampur }\end{array}$ & $\begin{array}{l}\text { Minor } \\
\text { Minor } \\
\text { Minor } \\
\text { Minor }\end{array}$ & $\begin{array}{l}\text { Minor } \\
\text { Minor } \\
\text { Minor } \\
\text { Minor }\end{array}$ \\
\hline 9. & Anthracnose & Colletotrichum graminicola (Ces) Wilson & 1965/Ilam & Minor & Minor \\
\hline 10. & Phyllosticta leaf spot & Phyllosticta zeae Stout & 1965/Godawari & Minor & Minor \\
\hline 11. & Diplodia leaf spot & Diplodia macrospora Earle. & 1966/Ilam & Minor & Minor \\
\hline 12. & Didymella leaf spot & Didymella sp. & 1965/ Nakkhu & Minor & Minor \\
\hline 13. & Leaf spot & Ascochyta zeae Stout & 1965/Khumaltar & Minor & Minor \\
\hline 14. & Leaf Spot & Phaeosphaeria maydis & 1977/Kakani & Minor & Minor \\
\hline 15. & Leaf Spot & Pithomyces chartarum (Berk and Crut) MB Ellis & 1964/Balaju & Minor & Minor \\
\hline 16. & Leaf spot & Trichothecium roseum (Pers) Link Ex. & 1965/Ilam & Minor & Minor \\
\hline 17. & Leaf Spot & Eudarluca austratis Speg. & 1964/Patan & Minor & Minor \\
\hline 18. & Mycosphaerella Leaf Spot & a. Mycosphaerella zeicola Stout & 1966/ Rampur & Minor & Minor \\
\hline & & Mycosphaerella $s p$ & & & \\
\hline
\end{tabular}




\begin{tabular}{|c|c|}
\hline 19. & Leaf spot \\
\hline 20. & Leaf spot \\
\hline 21. & Leaf spot \\
\hline 22. & Leaf spot \\
\hline 23. & Leaf spot \\
\hline 24. & Leaf spot \\
\hline 25. & Leaf spot \\
\hline 26. & Leaf spot \\
\hline 27. & Leaf spot \\
\hline \multicolumn{2}{|c|}{ Smut } \\
\hline 28. & Head smut \\
\hline 29. & Common smut \\
\hline 30. & False smut \\
\hline \multicolumn{2}{|c|}{ Cob /Ear rot } \\
\hline 31. & Fusarium Kernel rot (Gray ear rot) \\
\hline 32. & Fusarium ear rot/ Gibberella ear rot \\
\hline 33. & Rhizoctonia ear rot \\
\hline 34. & Diplodia ear rot \\
\hline 35. & Gray ear rot \\
\hline 36. & Cob rot \\
\hline 37. & Ear rot \\
\hline 38. & Ear rot \\
\hline 39. & Ear rot \\
\hline 40. & Ear rot \\
\hline 41. & Ear rot \\
\hline \multicolumn{2}{|c|}{ Stalk rots } \\
\hline 42. & Fusarium stalk rot \\
\hline
\end{tabular}

\section{Phaeoseptoria sp.}

Drechslera sp.

Phoma sorghina Boerma, dorenbosoch and

Vankent

Pestalotiopsis sp.

Hendersonia culmicola Sacc.

Phoma insidiosa Taasi

Coniothyrium sp.

Pyrenochaeta indica Viswanathan

Aureobasidium pullulans (Debary) Aranand.

Sphacelotheca reiliana (Kuehn) Clinton

Ustilago maydis (D.C.) Corde

Ustilaginoidea virens (Cke) Tak.

Fusarium moniliforme Sheld or Gibberella fujikuro (Saw) Wr.

Fusarium graminearum or Gibberella zeae (Saw)

Petch.

Rhizoctonia zeae Voorhees

Diplodia maydis (Berk) Sacc.

Physalospora zeae Stout.

Nigrospora oryzeae (Berk and Berk) Petch.

Cephalosporium acremonium $\mathrm{Cda}$.

Aspergillus sp.

Penicillium sp.

Trichoderma viridae Perx.ex. Fries

Helminthosporium $s p$.

\begin{tabular}{|c|c|c|}
\hline 1966/ Gokarna & Minor & Minor \\
\hline 1974/Kakani & Minor & Minor \\
\hline 1974/Kakani & Minor & Minor \\
\hline 1971/Kathmandu & Minor & Minor \\
\hline 1971/Kathmandu & Minor & Minor \\
\hline 1971/Rampur & Minor & Minor \\
\hline 1970/Rampur & Minor & Minor \\
\hline 1968/Parwanipur & Minor & Minor \\
\hline 1974/Kakani & Minor & Minor \\
\hline 1978/Rampur & Minor & Minor \\
\hline 1966/Ilam & Minor & $\begin{array}{l}\text { Major } \\
\text { (Sporadic) }\end{array}$ \\
\hline 1971/Ilam & Minor & Major \\
\hline 1965/Parwanipur & Minor & Minor \\
\hline 1974/Kakani & Major & Major \\
\hline 1974/Kakani & Minor & Major \\
\hline 1975/Pokhara & Major & Minor \\
\hline 1974/Kakani & Minor & Minor \\
\hline 1974/Kakani & Minor & Minor \\
\hline 1974/Kakani & Minor & Minor \\
\hline 1974/Kakani & Minor & Minor \\
\hline 1974/Kakani & Minor & Minor \\
\hline 1974/Kakani & Minor & Minor \\
\hline 1976/Kakani & Minor & Minor \\
\hline 1976/Kakani & Minor & Minor \\
\hline 1971/Rampur & Minor & Minor \\
\hline
\end{tabular}

a. Fusarium moniliforme Scheld (Gibberella 1971/Rampur $\quad$ Minor Minor b. Fusarium graminearum Schw. 


\begin{tabular}{|c|c|c|c|c|c|}
\hline 43. & Pythium stalk rot & Pythium aphanidermatum (Eds) Fitz. & 1971/Kathmandu & Minor & Minor \\
\hline 44. & Diplodia stalk rot & Diplodia maydis (Berk) Sacc. & 1971/Rampur & Minor & Minor \\
\hline 45. & Charcoal rot & Macrophomina phasiolina (Tassi) Goid & 1974/Kakani & Minor & Minor \\
\hline 46. & Black-bundle disease & Cephalosporium acremonium Cda. & 1970/Rampur & Minor & Minor \\
\hline \multicolumn{6}{|c|}{ Downy mildews } \\
\hline 47. & Sorghum downy mildew & Sclerospora sorghi (Kulk) Weston and Uppal & 1970/Rampur & $\begin{array}{l}\text { Major } \\
\text { (Sporadic) }\end{array}$ & Minor \\
\hline 48. & Philippine downy mildew & Sclerospora. Philippinensis Weston. & 1967/Rampur & $\begin{array}{l}\text { Major } \\
\text { (Sporadic) }\end{array}$ & Minor \\
\hline 49. & Brown-strip downy mildew & Sclerospora. rayssiae ver. Zeae, Payak and Renfro. & 1970/Rampur & Minor & Minor \\
\hline \multicolumn{6}{|c|}{ Bacterial diseases } \\
\hline 50. & Bacterial stalk rot & Erwinia carotovora (Jones) & 1968/Rampur & Major & Minor \\
\hline 51. & Bacterial leaf strip & Xanthomonas rubrilineans & 1976/Rampur & Minor & Minor \\
\hline 52. & Stewart wilt & Erwinia stewartii (E.F. Smith Dye) Dowson. & 1978/Rampur & Minor & Minor \\
\hline \multicolumn{6}{|c|}{ Virus diseases } \\
\hline 53. & Leaf fleck & Maize leaffleck virus & Rampur & Minor & Minor \\
\hline 54. & Mosaic & Maize mosaic virus & Rampur & Minor & Minor \\
\hline
\end{tabular}

\section{METHODOLOGY}

Explanation of the major maize diseases, their causal organisms, distribution, time and intensity of disease incidence, symptoms, survival, spreads, environmental factors for disease development, yield losses and various disease management strategies corresponded to important maize diseases of Nepal are collected and piled up thoroughly from the available publications. Results are summarized in tables, charts and texts with definite review of the important maize diseases and their management in Nepal.

\section{Major fungal diseases}

The majority of the maize diseases were foliar fungal diseases. Most of these diseases are distributed throughout the higher elevations of the mountains, hills and the terai. Some of the foliar diseases are favored by warm and humid conditions and others prevail in cool and humid conditions. 


\section{Gray Leaf Spot (GLS)}

Gray leaf spot (GLS) disease caused by Cercospora zeae maydis Tehon \& Daniels is a serious threat to farmers and has caused serious losses in grain yield of maize in 2006 (Manandhar et al., 2011). The disease was first identified from the state of Illinois, USA in 1925 (Tehon \& Daniels, 1925). Its occurrence was recorded in the Kavrepalanchowk district of Nepal (Manandhar, 2007). Grain yield losses of maize of up to 19 percent and 18 percent, respectively, on the local variety and on the improved OPV (Ganesh -1) were observed in field experiments (Manandhar and Baidya, 2010). The severity of GLS was high in the high hill region affecting adversely farmers who live with limited resources. The disease has been observed spreading over the years in 17 districts in the eastern, central and mid western regions of the country (Manandhar et al., 2009). GLS is evident on plants as small spots first on lower leaves of plants at tassel initiation. The disease moves upwards and spots change into long characteristics lesions within a month turning plants into a diseased field. The disease is significant since it rapidly destroys foliage when the plant is near at grain maturity (Manandhar et al., 2011).

\section{Management}

\section{Source of disease resistance}

Genotypes of maize including Corpoica H-112, CLA 87/CLA 91 from Colombia, and ZM 627, ZM 525, 05 SADVI, 07 SADVI, ZM 401 and ZM 501 from Zimbabwe were identified as resistant to GLS (Manandhar et al., 2011). The OPVs like Ganesh-1, Deuti, Manakamana-1 and Manakamana-3 (Ganesh-1 for high hills), can reduce yield loss in GLS prone environments of the hills (Manandhar et al., 2011). Experiment conducted at Pakhribas, Dhankuta revealed that genotypes ZM-627, 02SADVIF2, ZM-401, 07SADVI, Ganesh-1 (ARSP), 05SADVI, Manakamana-3 (ARSP) and ZM-423 were moderately resistant again GLS (NMRP, 2012). Genotype 07SADVI was found highly resistant against GLS and produced 9.12t/ha grain yield and other moderately resistant genotypes were SOOTLWQ-B, RampurSO3FQ-02, Manakamana 6 and S01SIYQ at Pakhribas (NMRP, 2013). The results of screening nurseries conducted in summer season of 2013 from different locations of the country for GLS resistant and high yielding genotypes are presented in the table 2 (NMRP, 2014).

\section{Cultural control}

An experiment conducted at Khumaltar revealed that the incidence of GLS was found lower in early planting maize compared to late sown crops (PPD, 2007).

\section{Northern Leaf Blight (NLB)}

The causal organism of this disease is Setosphaeria turcica Luttrell (Helminthosporium turcicum (Pass) Leonard and Suggs). The pathogen first identified in the country in 1964 (Khadka and Shah, 1967; Manandhar, 1980; Dahal et al., 1982). The disease is widely distributed throughout the country; however it is more prevalent in the cool and humid conditions of the foothills. It was not considered as the major disease of maize crop in Nepal until 1985. It is also common in the winter maize of the terai region. The disease usually 
appears before tasseling and became the most important disease at present. Maize late sown in the season is most affected by this disease in hills (Manandhar et al., 2007). The lesions of northern leaf blight can be observed together with other diseases on same or on different leaves of the plants. Greenish tan lens-shaped lesions on leaves are the characteristic symptoms of the disease. In the beginning, dark grayish green watersoaked oval areas appear on leaves. The disease is systematic in nature and lesions spread upward up to the top most leaves and sometimes the symptom is seen on the husk cover of ears. Lesions after coalescing each other cover a large area causing plants to dry and showing blighting appearance. Spores develop heavily in the middle of lesions with black velvet like appearance. Stalks of severely diseased plants become weak and they easily lodge. Hybrid genotypes of maize have also been affected by this disease in hills. Heavy losses could be incurred with a severe incidence of the disease. Severe infection has been already reported at Nijgadh, Bara during winter season maize at 2012 and also significant damage has been caused to the crop (NMRP, 2013).

\section{Management}

\section{Source of disease resistance}

Most of the maize genotypes so far tested was observed susceptible to moderately susceptible to the disease. However some genotypes have been found moderately resistant to the Northern leaf blight in different location during different year of experimentation (Table 3).

Table 2: GLS resistant and high yielding genotypes from different locations of the country during summer season of 2013

\begin{tabular}{|c|c|}
\hline Locations & GLS resistant and high yielding genotypes \\
\hline Kapurkot, Salyan & $\begin{array}{l}\text { YML32/(P147-F2-134-S7/P33-C3-64-S5)-F2- } \\
\text { B-7-3-1, } \\
\text { CML226/ CATETO)F2-B-1-2-B, YML32/(P147-F2-108-S7/P45-C8-76-S5)- } \\
\text { F2-B-30-1-3, } \\
\text { YML32/Cel FSRYS9956-B-3-2-4-B, YML 58/(G34/36/G33TSR)-F2-B-3-1-B, } \\
\text { YML } \\
\text { 58/(G34/36/G33TSR)-F2-B-4-1-B, YML58/(SEY90-C1\#/G34/36-B)-F2-B-2-1- } \\
\text { B, Yunrui } \\
\text { 505 } \\
\text { YML23/P502-C2 -58-1-1-2-5-B, YML 23/P502-C2-185-3-4-1-3-B-1-B, } \\
\text { YML23/P502-C3 - } \\
\text { F2-10-8-1-1-B, YML 23 /GLSI01P502-B-25-2-B, YML23/P44-C10-HS8-30-2- } \\
\text { 2-1-B, } \\
\text { YML23/P44-C10-HS8 -30-4-B-4-1- YML23/(MBR/MDR-C3W)-F44-2-2-1- } \\
\text { B, } \\
\text { YML23/GLSI01HGA }\end{array}$ \\
\hline Subedi. 2015 & YS12Q-189, \\
\hline $\begin{array}{l}\text { Suping, } \\
\text { Makawanpur }\end{array}$ & $\begin{array}{l}\text { RML-4/RML-17, RML-32/RML-17, GLSY, ZM-401, } \\
\text { ZM-627 } \\
\text { YML 23/P502-C2-185-3-4-1-3-B-1-B, YML } 23 \text { /GLSI01P502-B-25-2-B, } \\
\text { YML23/P502-C2- } \\
\text { 58-1-1-2-5-B, YS12Q-189, YS 12Q-71, YML 23/GLS101HGA-B-4-1-B }\end{array}$ \\
\hline
\end{tabular}


Table3: Reaction of maize genotypes to NLB disease in different locations during different year of experimentation

\begin{tabular}{|c|c|c|c|c|}
\hline Type & Location/Year/Season & $\begin{array}{c}\text { Total } \\
\text { test } \\
\text { entries }\end{array}$ & Moderately resistant genotypes & Reference \\
\hline \multirow[t]{3}{*}{ Inbreds } & Rampur/2004 -Winter & 55 & $\begin{array}{l}\text { RL-47, RL-12, RL-31, CA00310, RL-57, CML-172, RL-16, CML-165, CML-164, CA 00314, } \\
\text { CLQG-2509 }\end{array}$ & Paudel et al., 2007 \\
\hline & Rampur/2005-Winter & 240 & RML-79, RML-80, RL-35A, RL-64, RL-34, RML-8, RL-75, RL-104 & Paudel et al., 2007 \\
\hline & Rampur/2006-Winter & 54 & RML-36, RML-3, NML-1, RL-106, RL-57 & Paudel et al., 2007 \\
\hline $\begin{array}{l}\text { OPVs/Synthetic } \\
\text { varieties }\end{array}$ & Rampur/2004 -Winter & 32 & SQGTLWQHGAB, SO3TLYQABO2 & Paudel et al., 2007 \\
\hline Varietal screening trial & Rampur/ 2006-Winter & 58 & $\begin{array}{l}\text { S99TLYQ-A, DRACON F1/DRACON F2, S99TLWQ-GHA, SOOTLYQ-B, CELAYA- } \\
\text { S99551WQ, S99TLGHA, Deuti, AC9942 x AC9944, RamSO3FO6, RamSO3FO2, Shitala, SIS - } \\
\text { IBP-UTYF }\end{array}$ & Paudel et al., 2007 \\
\hline F1 Hybrids & Rampur/ 2006-Winter & 266 & $\begin{array}{l}\text { RL } 111 \text { x RL 189, RL } 160 \text { x RL 176, RL } 128 \text { x RL 169, RL } 105 \text { x RL 168, RL } 130 \text { X RL 169, } \\
\text { RL } 83 \text { X RL 155, RL } 82 \text { X RL 150, RML } 4 \text { X RML 3, RML } 3 \text { X NML 2, RC X RL 12, RL } 14 \text { X } \\
\text { RML 8, NML } 2 \text { X RL 12, RML 52 X RML 51, RML } 6 \text { X NML 2, RC X RML 17, RC X RML 3, } \\
\text { NML } 2 \text { X RL 17, NML } 1 \text { X RML 8, RL } 47 \text { X RML 5, RML } 6 \text { X RML 8, RL } 47 \text { X RL } 30-1 \text {, } \\
\text { RML } 8 \text { X RL 30-1, Bioseed 9681, RML } 13 \text { X Khumal Yellow, RML 52 X Khumal Yellow, RL } \\
\text { 43 X Khumal Yellow, RML 59 X Khumal Yellow, RML } 60 \text { X Khumal Yellow, RL 28 X } \\
\text { Khumal Yellow, RL } 13 \text { X Kumal Yellow, RL } 190 \text { X Khumal Yellow, RL } 67 \text { X Khumal Yellow }\end{array}$ & Paudel et al., 2007 \\
\hline \multirow[t]{4}{*}{ OPVs } & $\begin{array}{l}\text { Pakhribas/(2003/2004- } \\
\text { Summer) }\end{array}$ & 20 & Ganesh-1, Manakamana-3, ZM 621 (Deuti), Madi local white & $\begin{array}{l}\text { Manandhar et al., } \\
2007\end{array}$ \\
\hline & Rampur / (2003/04- Winter) & 18 & $\begin{array}{l}\text { Ganesh-1, ZM } 621 \text { (Deuti), Banglore 9745, Hill Pool Yellow, Rampur Composite, Manakamana - } \\
3\end{array}$ & $\begin{array}{l}\text { Manandhar et al., } \\
2007\end{array}$ \\
\hline & Lumle / (2003/04-Summer) & 21 & $\begin{array}{l}\text { Population 44, Manakamana-3, ZM } 621 \text { (Deuti), Ganesh-1, Hill Pool White, Hill Pool Yellow, } \\
\text { Ganesh-2, Manakamana-1 and PM-5 }\end{array}$ & $\begin{array}{l}\text { Manandhar et al., } \\
2007\end{array}$ \\
\hline & $\begin{array}{l}\text { Khumaltar / (2003/04- } \\
\text { Summer) }\end{array}$ & 18 & $\begin{array}{l}\text { Ganesh-1, ZM } 621 \text { (Deuti), Manakamana-3, Hill Pool Yellow, Hill Pool White, Banglore 9745,, } \\
\text { Rampur Composite, Manakamana-1, Madi local white }\end{array}$ & $\begin{array}{l}\text { Manandhar et al., } \\
2007\end{array}$ \\
\hline \multirow[t]{2}{*}{ Full season maize } & Rampur /(2009-Winter) & 21 & RampurS03F04, RampurS03F02, S99TLYQ-B, RampurS03F08, TLBRSO7F16 & NMRP, 2010 \\
\hline & Rampur /(2010-Winter) & 24 & RampurS03F02, S99TLYQ-B, RampurS03F08, BGBY population, Across 931, Takfa 0024 & NMRP, 2011 \\
\hline $\begin{array}{l}\text { Early maturing maize } \\
\text { (OPV/Synthetic) }\end{array}$ & Rampur /(2009-Winter) & 19 & S02SADVIF2, EEYC1, S97TEYGHA8B (3), S01SYNZIME & NMRP, 2010 \\
\hline Genotypes & Rampur/ (2011-Winter) & 32 & $\begin{array}{l}\text { PHRAPHUTTRBATS0031, TLRBSO7F16, SO19YNZIME, TLBR07F-14, BGBY-POP, } \\
\text { COMPOZNIBP, RampurS03F02, R-POP 1, Upahar }\end{array}$ & NMRP, 2012 \\
\hline OPVS/Synthetic variety & Rampur/ (2012/13-Winter) & 25 & RML-105, BGBYPOP, Across 9942/9944 & NMRP, 2013 \\
\hline OPVS/Synthetic variety & Rampur/ (2013/14-Winter) & 25 & $\begin{array}{l}\text { RML-17, RML-96, RML-86, RML-19, RML-32/RML 17, RML-4/RML-17, RL-151/RL-111, } \\
\text { 07SADVI, 05SADVI, ZM } 627\end{array}$ & NMRP, 2014 \\
\hline
\end{tabular}




\section{Southern Leaf Blight (SLB)}

This disease caused by Helminthosporium maydis Nisik and Miye, is most common in the Terai region but is also found in some pockets of the mountains and the valleys. The disease usually appears at the time of tasseling. The perfect stage Cochliobolus heterosporus Dreschst is also recorded from Chitwan valley (Manandhar, 1983). Southern corn leaf blight occurs worldwide

and important in regions of warm damp climate of 20-30 C temperature (Agrios, 2005). A long dry period of sunny weather between rains is unfavorable to disease development. This disease reached epidemic proportion in 1970 in USA resulting in losses estimated at one billion dollars (Ullstrup, 1972). The epidemic was caused by Race T attacking corn with Texas male sterile cytoplasm (T cms) which comprises $85 \%$ of corn acreage at that time. Race $\mathrm{O}$ occurs mainly in subtropical and tropical areas, where it causes minor losses. Yield reduction up to 50\% was recorded (Fisher et al., 1976, Gregory et al., 1978). The disease has been occurring in terai, inner terai and mid hills (lower elevation) since many years in summer and winter maize in Nepal (Paudel and Koirala, 1995). The fungus remain over winter as mycelium and spores in maize debris in the field and race $\mathrm{T}$ on kernels in cribs, bins, elevators. The conidia are carried out by wind or splashing water to growing plants where primary infection occurs. Sporulation on the lesions produces additional primary or secondary inoculums. The disease cycle can be completed in about 60-72 hrs (Race T) under ideal conditions (Agrios, 2005).

\section{Management}

\section{Source of disease resistance}

From observation and experiences it has been found that early genotypes are more prone to Southern Leaf Blight disease as compared to full season varieties (Paudel et al., 2007). Efforts have been made to select SLB resistant genotypes and presented in table 4.

\section{Banded leaf and sheath blight (BLSB)}

The disease is caused by Rhizoctonia solani (Kuhn); its perfect stage is Thanatephorus cucumeris (Frank) Donk and mostly localized in the inner terai (Manandhar, 1983). The disease was first noted in 1977, and its incidence has been increasing in Nepal. Under natural conditions, disease appears at pre-flowering stage on 30 to 40 days old plants, but infection can also occur on young plants. The disease appears on basal leaf sheaths as water soaked, straw colored, irregular to roundish spot on both the surfaces. Profuse mycelia growth is seen on the affected areas of leaf sheath and in between the leaf sheath and stem. Later on as the infection becomes older, numerous sclerotial bodies develop on the affected parts (Agrios, 2005). The disease after its occurrence causes direct loss due to premature death, stalk breakage, destruction of leaves, leaf sheaths and ear rot. Banded leaf and sheath blight of maize is known under various names, viz; sclerotial disease, sharp eye spot, oriental leaf and sheath blight, Rhizoctonia ear rot, sheath rot and corn sheath blight etc (Rijal et al., 2007). It is a destructive plant pathogen with an almost unlimited host range. It aggressively colonizes organic debris and thus has enough saprophytic survival ability. No sexual spores are formed and only sclerotia formed as soil borne propagules. The sclerotia are knots of undifferentiated, 
intertwined, pigmented monilioid cells. The symptoms of the disease are observed on all aerial parts of the plant except tassel. The disease manifests itself on leaf, leaf sheath, stalk and ears as leaf and sheath blight. Losses to the extent of $10-90 \%$ have been reported on different maize varieties /cultivars (Singh and Sarma, 1976; Butachaiah, 1977).

\section{Management}

\section{Source of disease resistance}

Out of several maize genotypes (inbreds/hybrids) screened against BLSB disease (table 5) under artificially inoculated conditions, very few genotypes showed resistant to moderately resistant reaction (Rijal et al., 2007). Most of the susceptible genotypes were collapsed at the time of final disease scoring (Rijal et al., 2007).

Table 4: Reaction of maize genotypes to Southern Leaf Blight (SLB) in different locations during different year of experimentation

\begin{tabular}{|c|c|c|c|c|}
\hline Type & $\begin{array}{c}\text { Location/Year/Seaso } \\
\text { n }\end{array}$ & $\begin{array}{c}\text { Total } \\
\text { test } \\
\text { entries }\end{array}$ & Moderately resistant genotypes & Reference \\
\hline \multirow[t]{2}{*}{ Inbreds } & $\begin{array}{l}\text { Rampur/2004 - } \\
\text { Summer }\end{array}$ & 20 & CML 451, CA 00310, CA 00314, RL 5, RL 12 & $\begin{array}{l}\text { Paudel } \text { et al., } \\
2007\end{array}$ \\
\hline & $\begin{array}{l}\text { Rampur/2005- } \\
\text { Summer }\end{array}$ & 52 & $\begin{array}{l}\text { RML-18, RL-14, NML 1, RML-6, RL-30, RML-16, } \\
\text { RML-18, RML-10, RL-12, RL-9, RML } 55\end{array}$ & $\begin{array}{l}\text { Paudel et al., } \\
2007\end{array}$ \\
\hline \multirow{5}{*}{$\begin{array}{l}\text { OPVs/Synt } \\
\text { hetic } \\
\text { varieties }\end{array}$} & $\begin{array}{l}\text { Rampur/2004 - } \\
\text { Summer }\end{array}$ & 19 & $\begin{array}{l}\text { Pop } 45 \text { C10, S99TLGAB (3), Pop44C10, Population 21, } \\
\text { ZM 621, Cotaxla S } 9627\end{array}$ & $\begin{array}{l}\text { Paudel et al., } \\
2007\end{array}$ \\
\hline & $\begin{array}{l}\text { Rampur/2005 - } \\
\text { Summer }\end{array}$ & 28 & $\begin{array}{l}\text { SOISIYQ, Cotaxla S9627, Rampur So3 Fo4, SO3 } \\
\text { TLYQAB-02, Narayani }\end{array}$ & $\begin{array}{l}\text { Paudel et al., } \\
2007\end{array}$ \\
\hline & $\begin{array}{l}\text { Rampur/2006 - } \\
\text { Summer }\end{array}$ & 44 & $\begin{array}{l}\text { Sitala, Banglore 9745, Rampur So3 Fo2, Pop45 C10, } \\
\text { Rampur So3 Fo8, Across 501, Takfa S9624, Takfa } \\
\text { S9636, Rampur So3 Fo6, Rampur So3 Fo4, S99 } \\
\text { TLYGHAB }\end{array}$ & $\begin{array}{l}\text { Paudel et al., } \\
2007\end{array}$ \\
\hline & $\begin{array}{l}\text { Rampur/2009- } \\
\text { Summer }\end{array}$ & 28 & $\begin{array}{l}\text { Posilo Makai-1, Rampur So3 Fo6, TLBRS07F16 (R), } \\
\text { RamS03F02, BLSBRS07F10 }\end{array}$ & NMRP, 2010 \\
\hline & $\begin{array}{l}\text { Rampur/2011- } \\
\text { Summer }\end{array}$ & 38 & $\begin{array}{l}\text { TLBRSO7F16, BLSBRS07F10, Across-9531, } \\
\text { BGBYPOP, TLBRS07F14, RampurS03F08 }\end{array}$ & NMRP, 2012 \\
\hline \multirow[t]{3}{*}{ Genotypes } & $\begin{array}{l}\text { Rampur/2012- } \\
\text { Summer }\end{array}$ & 20 & $\begin{array}{l}\text { TPY, BLSBSO7F10, BLSBSO7F12, TLBRSO7F14, } \\
\text { TLBRSO7F16, Across 9331 RE, HG-AB, RML-8/AC, } \\
\text { Celaya 00HGYA/00HGYB, R-POP- 3, RML-4/NML-2, } \\
\text { RML-32/RML-17, RML-4/RML } 17\end{array}$ & NMRP, 2013 \\
\hline & $\begin{array}{l}\text { Rampur/2013- } \\
\text { Summer }\end{array}$ & 30 & $\begin{array}{l}\text { JH-1203, SYN312-SR, CML-444/CML-489, SYN 312- } \\
\text { SR, CML-312/CML-444, CML-395/CML-444, }\end{array}$ & NMRP, 2014 \\
\hline & & & CZH0838, CZH1108, ZH-1204, CML-305/CML 444 & \\
\hline
\end{tabular}

\section{Biological control}

All the isolates of Trichoderma spp exhibited antagonistic activities against $R$. solani $\mathrm{f}$. sp. Sasakii. The degree of antagonism in terms of inhibition of growth of mycelium, production, mass and viability of sclerotia of the pathogen was highly variable among the isolates. Among the seven isolates evaluated Trichoderma Koeningii TKB-1 exhibited maximum inhibition (51.5\% (46.7\%). Similarly Trichoderma 
viridae -TVB-1 (76.9\%) showed maximum reduction of sclerotia production. A complete reduction in the viability of sclerotia was recorded in case of THB-1 and TSB-67 (Batsa et al., 2004). Batsa et al., (2004) studied about the comparative efficacy of cultural, chemical and biological control against BLSB in maize and found that the cost of BLSB control was minimum in leaf stripping however validamycin provided maximum (Rs 5.88) return from each rupee investment. Since BLSB spreads upward from the base of plants through sheath to sheath contact; leaf stripping breaks this contact restricting the upward movement of pathogen by $100 \%$. Hence Leaf stripping technique is also suggested for BLSB management in maize.

Table 5: List of different moderately resistant maize genotypes tested against BLSB in different locations and year.

\begin{tabular}{|c|c|c|c|c|}
\hline Type & $\begin{array}{l}\text { Location/Year/S } \\
\text { eason }\end{array}$ & $\begin{array}{c}\text { Total } \\
\text { test } \\
\text { entries }\end{array}$ & Moderately resistant genotypes & Reference \\
\hline Inbreds & $\begin{array}{l}\text { Rampur/2006 - } \\
\text { Summer }\end{array}$ & 40 & $\begin{array}{l}\text { RML-8, RML-12, RL-84, RL-181, RL-155, RML-10, RL -28, RL- } \\
\text { 180, RL-140, RL-47, NML-2, RL-13, RML-41, RL-106 }\end{array}$ & $\begin{array}{l}\text { Rijal et al., } \\
2007\end{array}$ \\
\hline Hybrids & $\begin{array}{l}\text { Rampur/2006- } \\
\text { Summer }\end{array}$ & 19 & $\begin{array}{l}\text { AG } 20 \text { X AG 27, } 108 \text { X AG 27, } 75 \text { X AG 27, } 114 \text { X AG 27, } 113 \text { X } \\
\text { AG-27, } 103 \text { X AG-27, } 16 \text { X AG-27, } 69 \text { X AG-27, } 105 \text { X AG-27 }\end{array}$ & $\begin{array}{l}\text { Rijal et al., } \\
2007\end{array}$ \\
\hline \multirow[t]{6}{*}{ Genotypes } & $\begin{array}{l}\text { Rampur/2009- } \\
\text { Summer }\end{array}$ & 63 & RML-4, RML-5, RML-8, PUTU-13, AG-27, L-1, L-7, L-3 & NMRP, 2010 \\
\hline & $\begin{array}{l}\text { Rampur/2010- } \\
\text { Summer }\end{array}$ & 12 & BLSBRS07F12, BLSBRS07F10, RML-8, Terai Pool Yellow & NMRP, 2011 \\
\hline & $\begin{array}{l}\text { Rampur/2011- } \\
\text { Summer }\end{array}$ & 20 & $\begin{array}{l}\text { Synthetic-C, BGBYPOP, BLBRS07F10, HG-A, TLBRSO7F16, } \\
\text { BG-B, R-Pop-3, R-Pop-4, SO3TLYQ-AB-02 }\end{array}$ & NMRP, 2012 \\
\hline & $\begin{array}{l}\text { Rampur/2012 - } \\
\text { Summer }\end{array}$ & 30 & $\begin{array}{l}\text { Terai Pool Yellow, TLBRSO7F16, HG A, R POP-4, Synthetic B, } \\
\text { Synthetic C, Across 9331 RE, BGBYPOP, Arun-1 EV, Pool-17, } \\
\text { 05SADVI, 07SADVI, GLSYW, RML-4/NML-2, RML-32/RML- } \\
17\end{array}$ & NMRP, 2013 \\
\hline & $\begin{array}{l}\text { Rampur/2013- } \\
\text { Summer }\end{array}$ & 30 & $\begin{array}{l}\text { DTM\#-25, DTM\#-27, DTM\#-28, DTM\#-30, DTM\#-36, DTM\#-37, } \\
\text { DTM\#-38, KEYPOP, KGPOP-2, KS } 12 \text { F12, } 05 \text { SADVI, } 07 \\
\text { SADVI }\end{array}$ & NMRP, 2014 \\
\hline & $\begin{array}{l}\text { Lumle/2013- } \\
\text { Summer }\end{array}$ & 30 & $\begin{array}{l}\text { DTM\#-23, DTM\#-35, DTM\#-36, DTM\#-32, DTM\#-38, ZM 401, } \\
\text { KGPOP-2, MHEY, KLYPOP }\end{array}$ & NMRP, 2014 \\
\hline
\end{tabular}

\section{Ear rot}

The preliminary study of this disease was initiated in 1974-75. A number of pathogens have been observed in Nepal. Among the various ear rotting organisms, Fusarium moniliforme Schw. was found to the most common and most destructive to the crop (Manandhar, 1976). Pathogens like Diplodia maydis (Berk) Sacc. and Rhizoctonia zeae Voorhees were also common in the mountains but the infection was very low. Although Fusarium ear rot is distributed throughout the country, it is most prevalent in the mountains with cool and humid weather conditions (Manandhar, 1976). In these areas, the crop stands for 6-8 months in the field and the high rainfall provides favorable conditions for disease incidence. The infection rate in the mountain is usually $30-40 \%$ whereas in the inner terai and the Kathmandu valley it is only about 5-10\% (Manandhar, 1983). In some varieties an intensity of infection of 80-90\% has been reported. Such intensity of infection results in very high losses in grain yield. The improved varieties of maize seem to be more susceptible to this disease than some of the local varieties (Shah and Manandhar, 1978). Fusarium graminearum Schwabe (teleomorph 
Gibberella zeae (Schw.) Petch, causes prominent Gibberella or red ear rot disease in high and mid hills. Red discoloration most common at tips of the ears and the husk leaves are recognizable symptoms of the disease at harvest. Severely affected ears are light and have tightly attached husk leaves. Numerous small black fruiting bodies of the fungus, a Gibberella state sometimes appear on husk covers or on other affected parts of the plant. The pathogen is common in injured areas caused by ear/kernel/silk-cut insects or birds and also on germinating kernels of the ears in lodged plants. Frequent rain or foggy weather prior to harvest enhances the ear rot disease and many high yielding maize varieties are susceptible to disease in high hills. The disease also appears later on harvested ears in high hills. Due to drying problem in high hills local maize is more popular among the farmers in spite of low grain yield or small size of the ears. The pathogen can also infect seeds/ seedlings/roots causing discolorations/rots/blights in field during germination in high hills. The incidence of ear rot was highest up to $40 \%$ in high hills like Kakani. It was moderate almost $20 \%$ in the eastern hills like Pakhribas and Kabre. Incidence of ear rot was in the range of $10 \%$ to $15 \%$ in the western hills at Jumla and Lumle, and lowest as below 5\% at Khumaltar and in terai at Rampur (Manandhar and Gurung, 1982). The pathogen is also important for the quality of the maize since it can produce trichothecenes deoxynivalenol and nivalenol mycotoxin on moldy kernels. The occurrence of trichothecenes mycotoxins contamination was detected in $16 \%$ of 74 maize samples collected from different parts of Nepal (Desjardins et al., 2000).

\section{Management}

\section{Source of disease resistance}

Resistant genotype is the only ideal means to overcome the yield reduction due to the disease. Evaluation of maize genotypes for resistant to ear rot disease was initiated in NMRP, Rampur and presented in table 6 .

Table 6: List of different moderately resistant maize genotypes tested against ear rot at Rampur in different year.

\begin{tabular}{|c|c|c|c|c|}
\hline Type & Location/Year/Season & $\begin{array}{c}\text { Total } \\
\text { test } \\
\text { entries }\end{array}$ & Moderately resistant genotypes & Reference \\
\hline \multirow[t]{5}{*}{$\begin{array}{l}\text { Genotyp } \\
\text { es }\end{array}$} & Rampur/2009-Summer & 63 & $\begin{array}{l}\text { AG-27, RampurS03F02, RampurS03F04, } \\
\text { RampurS03FQ2, BLSBRSO7F110, BLSBRS07F12, } \\
\text { TLBRS07F14, TLBRS07F16, RPop-3, NML-1/NML-2 } \\
\text { (Gaurav), RML-4/NML-2, RML-8/Rampur composite }\end{array}$ & $\begin{array}{l}\text { NMRP, } \\
2010\end{array}$ \\
\hline & Rampur/2010-Summer & 12 & Terai Pool Yellow, RampurS03F06, RML-8 & $\begin{array}{l}\text { NMRP, } \\
2011\end{array}$ \\
\hline & Rampur/2011-Summer & 20 & Across 033, R-Pop-3, Synthetic-B, TLBRSO7F16 & $\begin{array}{l}\text { NMRP, } \\
2012\end{array}$ \\
\hline & Rampur/2012-Summer & 20 & HG 'A', SO3TLYQ-AB-02, Synthetic-A & $\begin{array}{l}\text { NMRP, } \\
2013\end{array}$ \\
\hline & Rampur/2013-Summer & 21 & $\begin{array}{l}\text { RML-98/RL-105, RML-68/RL-101, RML-8/RML-62, RL- } \\
\text { 197/NML-2, RL-180/RML-5, ZM-401 }\end{array}$ & $\begin{array}{l}\text { NMRP, } \\
2014\end{array}$ \\
\hline
\end{tabular}




\section{Stalk rot}

This group of diseases is broadly divided into two categories, namely pre-flowering and post-flowering types. The former category includes stalk rots such as Pythium stalk rot [Pythium aphanidermatum (Eds.) Fitzp.] and bacterial stalk rot [Erwinia chrysanthemi pv. zeae (Sabet) Victoria, Arboleda \& Munoz], whereas others, such as Fusarium wilt, late wilt, black bundle disease and charcoal rot, appear in the postflowering phase. Stalk rot is distributed throughout the country, but it is most prevalent in the hot and humid areas (Shah, 1968); however pythium stalk rot is found to be common in the mountains and the valleys in Nepal (Diwakar and Payak, 1975). The disease usually appears at the tasseling stage.

\subsection{Pythium stalk rot}

This stalk rot is known to cause extensive damage to the crop in the lowlands of northern India and southern Nepal. The incidence of disease is significantly influenced by both environmental and host factors. Temperature and relative humidity have been found to affect both the growth of the pathogen and disease development. The maximum disease development occurs within a temperature range of $30-35^{\circ} \mathrm{C}$, with a relative humidity of $80-100 \%$. Waterlogged, low-lying or poorly drained field conditions favor a high degree of disease development. Plant age (pre-flowering growth stage) and a large plant population ( $\geq 60000$ per ha) favor a high incidence of disease (Diwakar and Payak, 1980).

Some resistant material has been identified. Hybrids Ganga Safed -2, Hi-starch, and composites Suwan 1 and Suwan 2, have shown resistance in India. An application of 75\% captan (11 .2 g a.i. per

1001 water applied as a soil drench at the base of the plant when the crop is 5-7 weeks old) can check this disease effectively (Payak and Renfro, 1974).

\subsection{Fusarium stalk rot}

Stalk rots incited by $F$. moniliforme Sheld. and $F$. graminearum Schw. are known throughout Asia; however, the incidence of the former is more severe in lowland tropical areas, whereas the latter is present in the cooler highlands. The symptoms become conspicuous after flowering and towards maturity, when plants show premature drying. The pathogen commonly affects the roots, crown region and lower internodes. When split open, the stalks show a pink-purple discoloration with collapse of the pith region (De Leon, 1984). In old plants affected by $F$. graminearum, blue-purple ascomata of Gibberella zeae develop on the outer surface of the stalk rind. The diseases are known to occur in Nepal, India, Indonesia, Pakistan, Philippines, Thailand and Vietnam. They are observed more commonly if there is a period of drought during or shortly after pollination. Agronomically desirable stalk rot-resistant materials are available in Pakistan, India, Mexico and Zimbabwe, where selections against these diseases have been made. The 'stay green' character, in which plants remain green after attaining physiological maturity, has been associated with resistance to certain post-flowering stalk rots. There is evidence of mammalian toxicity where stalks infected with these pathogens

\section{$7 \quad$ Head smut}


Head smut caused by Sporisorium reiliana (Kuhn) Langdon \& Full. (Syn. Sphacelotheca reiliana (Kuhn) Clinton or Ustilago reiliana Kuhn is a sporadic disease of maize in Nepal. Incidence of the smut disease was first recorded from Ilam in 1966 (Khadka and Shah, 1967). The disease is widespread in hilly regions of the country and is familiar among farmers because of its black sori often with phyllody or other abnormal symptoms in tassel and ears (Gurung et $a l .$, 1985). Generally the tassel or ears are completely or partially replaced by smut balls or leafy proliferations. The soil borne spores infect the plants during emergence or at the seedling stage and grow systematically with the meristem (Xu et al., 1999). The symptoms on the tassel often indicate presence of the smut pathogen in a maize field. Infected plants with normal tassels are also common. The ear in such plants can be seen smutted only at harvest. From time to time farmers have reported the smut problem in their fields. Head smut was noted on ears of variety Manakamana-1 at Pakhribas, Dhankuta in 1983. It also caused failure in seed production with the occurrence of the smut $30 \%$ and $10 \%$ respectively on varieties khumal yellow and Arun-2 during

1987 growing season (Manandhar, 1992). Incidence reached 75\% on local maize 'Ashare' planted in February in Dhading during 1992. Ashare is harvested in June -July for maize-rice system at the foothills near Khanikhola. The smut incidence was reported as $100 \%$ on plants of some kitchen gardens grown for green ear consumption in Kathmandu Valley including Ramkot. Losses due to disease of $30 \%$ and above were reported in farmers field in epidemic years at Patlikhet village of Myagdi (Pradhananga and Ghimire, 1996; Ghimire and Harding, 1997). In Lalitpur, smut incidence up to $60 \%$ was reported from Chunnikhel (W-7), Dhapakhel (W-3) and Thuladurlung (PPD, 2000). Farmers of Kulekhani asked remedies for smut problem. Its occurrence is reported mainly in hilly districts like Jumla, Kaski, Dolakha, Tehrathum, Sindhupalchwok and Nuwakot.

\section{Management}

1. Resistant cultivars: Sweet corn, Pop corn Hybrid B840 (Manandhar, 2002)

2. Seeding date: Smut incidence was noticed in decreasing trend with the highest percent in April or early May sown plants as compared to that sown in late May or June (Manandhar, 2002).

3. Seed treatment: Out of 15 fungicides, Sumi-8, Tilt-100, Raxil-2, Baytan-10 and Bayleton-5 have proved effective against the smut (Manandhar, 2002)

\section{Common rust}

This rust, caused by Puccinia sorghi Schw., develops on maize plantings in subtropical conditions in Nepal, Bhutan, South China and northern India. Aecial infection occurs infrequently on Oxalis spp. in Nepal. O. corniculata has been found to be susceptible under conditions of artificial inoculations with teliospores of $P$. sorghi in India. However aecial infections, so far, have not been observed in nature. Since the early 1970s in the state of Bihar, India, winter plantings have suffered epidemics of this rust, mainly because of the cultivation of the susceptible hybrids Ganga Safed-2 and Hi-starch (Sharma et al., 1993). In summer maize the incidence of the disease is quite high in the mountains and the valleys with very little disease incidence noted in the terai; however the disease has attacked the winter and spring maize of the terai in Nepal (Kashalappa and Hedge, 1970). The disease usually appears at the Knee-high stage or at tasseling. The local varieties of maize are highly susceptible to this disease which means that common rust existed in Nepal long before it was first reported in 1964 (Manandhar and Sah, 1972). Losses in grain yield ranging from 6 to $32 \%$ have been reported (Sharma et al., 1982). The inheritance of generalized or mature plant resistance has been studied by Sharma and Payak 
(1979) and has been established to be polygenic, with a small number of genes conditioning resistance. Cultivars possessing resistance are available in most countries. For seed production and susceptible cultivars of pop corn and sweet corn, two to three spray applications of the fungicide zineb are recommended.

\section{Downy mildews}

This group of pathogens constitutes one of the most important factors limiting maize production in South and South-East Asia. The important species causing downy mildew (DM) in maize in the region are the Philippine DM [Peronosclerospora philippinensis (Weston) Shaw], Sorghum DM [P. sorghi (Weston \& Uppal) Shaw], Java DM [(P. maydis Raciborski) Shaw], Sugar-cane DM [P. sacchari (Miyabe) Shirai \& Hara] and Brown stripe DM (Sclerophthora rayssiae var. zeae Payak and Renfro). It is most common in the warm and humid weather conditions of the Terai region (Shah, 1968). The infection rate is usually 10-20\% but when the weather is very wet and humid, the disease may become epidemic and the infection rate rise can to 30-60\% (Manandhar, 1972). The disease appears when the plants are 3-4 weeks old. The losses incurred in heavy infection are 10-20\% reduction in grain yield. Heavy infections have been most commonly observed in late sown (June-July) crops (Manandhar, 1975). The symptoms of the carry top like deformation has been observed in the inner terai since 1975. However the causal organism has yet not been established accurately (Manandhar, 1981).

\subsection{Philippine downy mildew}

This pathogen is widespread in the Philippines, plains of Nepal and northern India, Laos and northern Vietnam. The disease was first reported in India in 1912. This DM has also been found to possess the highest level of virulence: yield losses of $40-60 \%$ are frequent, and a disease incidence of 80-100\% is not uncommon (Exconde, 1970). In Nepal, the disease developed in an epidemic form in 1987, with losses as high as $50 \%$. It has been observed that late-sown plantings suffer greater damage (Shah and Tuladhar, 1971). Infection on maize is traceable to the proximity of infected clumps of the wild grass Saccharum spontaneum. The grass not only grows wild but also is planted as fencing around cultivated fields. Its eradication helps to eliminate this DM. Resistance in the Philippines is derived from indigenous open-pollinated varieties, particularly Tiniguib and Impa-Impa, others being Aroman White Flint, Kabacan WF, Bukidnon WF, Cadlan WF, Cebu WF, College WF and Bicol WF (Aday, 1975). The composites and varieties developed in the Philippines are based on crosses of local and introduced germplasm such as Tuxpeno, Eto Amarillo, Eto Blanco, Cupurico, Cuba Gr.l, and Tuxpantigua. A series of composites such as Phil DMR-1 and DMR-5 have been released for cultivation.

\subsection{Sorghum downy mildew}

This pathogen was first recorded in teosinte (Zea mays ssp. mexicana) from Pune in 1905, and in 1907 on sorghum from India (Butler, 1907; Uppal and Desai, 1932). Since the 1960s, damage on maize and sorghum has been observed to have a cosmopolitan distribution. Three strains have been identified in $P$. sorghi -the sorghum strain (infecting only sorghum), the maize strain (attacking maize only) and a strain that infects both crops. In Thailand, only the maize strain of $P$. sorghi has been reported; in India, all three strains of the pathogen have been recorded (Payak et al., 1979). On the basis of isozyme analysis, Bonde et al. (1984) reported 
that the Thai isolate has only four alleles out of 15 in common with those present in the five other isolates of $P$. sorghi. On the basis of isozyme analysis, the Thai isolate was more closely related to the 'P. sacchari-P. philippinensis complex' than to $P$. sorghi. The fungus can inflict serious damage in introduced germplasm with no resistance. The DM-resistant cultivar Suwan 1, released in Thailand in 1973, spread rapidly throughout most Asian countries where it continues to show a good level of DM resistance. Selections of Suwan 1 have been released in Nepal, Bhutan, Burma, South China, India, Indonesia, Laos, Philippines, Sri Lanka and Vietnam. In Thailand, $80 \%$ of the area planted to maize has been covered by this high-yielding DM-resistant improved open-pollinated cultivar. Several CIMMYT maize populations (populations 22, 28, 31, 72, 75 and 78) have been selected by the CIMMYT-Asian Regional Maize Programme (CIMMYT, 1989); these combine desirable agronomic characters and a broader genetic base for DM resistance. Several other cultivars, such as Suwan 2 (early selection from Suwan 1), Suwan 3, Nakorn Sawan 1 (NSI), Rampur 8075, and Ganga 11 (male parent Suwan 1) have been released by national programmes in Nepal, Thailand and India. In Thailand the agronomic practice of early planting in the rainy season is recommended for a low disease incidence. Late plantings are normally more damaged, mainly due to higher moisture and inoculum load.

\subsection{Brown stripe downy mildew}

This disease was first reported from India (Payak and Renfro, 1967). It has also been found in Burma, Nepal, Pakistan and Thailand (Frederiksen and Renfro, 1977), but is unknown outside South and South-East Asia. In the Himalayan area of northern India, the disease is limited to locations below $1500 \mathrm{msl}$ (meters above sea level). Yield losses of up to $63 \%$ have been recorded in the tarai area of Uttar Pradesh (Sharma et al., 1993). As well as affecting maize, the disease has also been recorded on teosinte, Digilaria sanguinalis, in India and on D. bicornis in Thailand. Several cultivars possessing resistance to this DM have been identified. However, the most outstanding cultivar has been hybrid Ganga 5, widely grown in India. Genetic resistance to the disease has been identified with both additive and dominant gene actions. However, additive gene action plays a greater part in the expression of resistance (Asnani and Bhushan, 1970; Singh and Asnani, 1975). Late plantings (mid-July or later) suffer greater damage (Payak, 1980). Resistance to maize DMs in general has been determined to be polygenic (Mochizuki, 1975; Singburaudom and Renfro, 1982). An exception is sugar-cane DM in Taiwan where a resistance factor was also found to be monogenic and dominant (Chang, 1969). Several fungicides have been tried for the control of DM in maize. Seed treatment with Oemosan (chloroneb) was found to be promising against sorghum DM in Thailand (Titatarn, 1976) and in India, on brown stripe DM and sugar-cane DM in India (Lal, 1975) and on Java DM (Triharso and Kusdiarti, 1976). In the Philippines, economic returns for a schedule of three spray applications of Ou-ter (fentin hydroxide) followed by Dithane M 45 (mancozeb) was claimed to be cost effective and feasible for use against Philippine DM (Exconde et al., 1975). Among the systemic fungicides, acylalanines and the related compounds metalaxyl (Ridomil 25 WP, Apron 35 SO, Apron 30 FW), furalaxyl (Fongarid WP G), milfuram (Patafol, Caltan WP) and benalaxyl (Galben WP G) have been very effective in controlling DM incited by Peronosclerospora and Sclerophlhora (Venugopal and Safeeulla, 1978; Exconde and Molina, 1978; Lal et al.1980; Renfro, 1983). 


\section{Brown Spot}

It is caused by Physoderma maydis Miyabe, the disease is widely distributed throughout the country. The disease usually appears at the time of tasseling. Severe incidences are found only in some parts of the inner terai and in Gulmi district. Losses have not been yet determined in Nepal. They have been reported non significant in India (Lal and Chakravarti, 1977). Normally the disease occurs in areas of abundant rainfall and high mean temperatures; it attacks the leaves, leaf sheaths, stalk and sometimes the outer husks. The first noticeable symptoms develop on leaf blades and consist of small chlorotic spots, arranged as alternate bands of diseased and healthy tissue. Spots on the mid ribs are circular and dark brown, while lesions on the laminae continue as chlorotic spots. Nodes and internodes also show brown lesions. In severe infections, these may coalesce and induce stalk rotting and lodging (CIMMYT Maize Program, 2004). Removal of plant debris and tillage operation minimizes the disease incidence in the maize field. Some tolerant maize varieties Manakamana-3, 4, 5 and 6 were released for the cultivation (Rijal, 2012).

\section{Bacterial disease}

Three bacterial diseases have been identified in Nepal.

\section{Bacterial stalk rot}

Bacterial stalk rot is caused by Erwinia carotovora and is generally confined to the terai. It is extended to some pockets of the mountains and Kathmandu valley but with very low rates of infection. The disease usually appears at the time of tasseling. Intensity of infection increases as weather conditions become warmer and humid (Manandhar, 1983). In the terai, the rate of stalk rot infection is high because $50 \%$ of the stalk rot is cause by corn borer damage and high percent of yield losses incurred. In the tarai area of northern India, and in southern Nepal and the southern Philippines, this disease represents a serious problem for maize production. It has been observed that a high disease incidence is associated with the use of sewage water for irrigation; it is particularly favoured by high temperatures $\left(\geq 28^{\circ} \mathrm{C}\right)$ and high relative humidity, which prevails in most maize-growing areas 3-4 weeks after sowing. In India, resistance in some inbred lines, single crosses and hybrids has been identified through artificial inoculations. Among these, CM 104, CM 600, hybrids Ganga Safed-2 and multiple disease resistant (MDR) populations MDR-1 and MDR-2 are known (Sharma et al., 1993). This pathogen is highly sensitive to chlorine (Thind and Payak, 1972). Efficient control of the disease by using bleaching powder

$\left(\mathrm{CaOCl}_{2} . \mathrm{H} 20\right.$ containing $33 \%$ chlorine), is achieved by drenching the basal stalk region when the plants are knee high.

\section{2. $\quad$ Bacterial leaf strip}

This disease caused by Xanthomonas rubrilineans was first reported by Manadhar in 1976. Its incidence has been extremely low. However in 1981 a severe infection appeared in epidemic form at Rampur, Chitwan (Manandhar, 1983).

\section{Stewart \\ Wilt}


This disease caused by Erwinia stewartii (E.F. Smith Dye) Dowson has been reported from a few places in the terai. Because the incidence of the disease is very low, yield losses attributed to it are negligible (Manandhar, 1983).

\section{Diseases caused by viruses}

The viruses reported on maize in the Asian region are maize mosaic virus I, maize mosaic virus (MMV) and vein enation virus in India (Sharma and Payak, 1983), maize dwarf mosaic virus (MDMV), corn stripe and what is reported as 'leaf gall' (probably maize rough dwarf virus) in the Philippines (Exconde, 1983) and MDMV in China (Zhu et al., 1983; Jingxiong, 1991). Incidences of virus diseases have been reported in Nepal, but none of the virus diseases have been unquestionably identified. The suspected virus diseases in Nepal are maize mosaic and leaf fleck (Manandhar, 1983).

\section{Nematodes}

Several nematodes have been found attacking maize. However, only the cyst nematode (Heterodera zeae Koshy, Swarup and Sethi) represents a serious problem in some maize growing areas (Koshy and Swarup, 1971). Carbofuran at $2 \mathrm{~kg}$ a.i. per ha is recommended for effective control. H. zeae can be managed by eradication of Setaria sp., an alternate host of the nematode, and by crop rotation (mainly by planting a non-susceptible crop).

\section{Pathogenic variability study}

Pathogenic variability observed among $F$. graminearum isolates from 3 cereal crops. Many virulent isolates were from maize. Out of 25,4 including 3 from maize and 1 from rice were the most virulent isolates. There were 2 different groups in maize and isolates were able to cause disease on other crops. Both nivalenol and deoxynivalenol trichothecenes mycotoxins producing isolates were frequent and were able to cause disease (Manandhar et al., 2007).

\section{Loss assessment study}

Several maize diseases have been identified as economically important in national perspective (Khadka and Shah, 1967; Manandhar, 1983). Yield losses due to various diseases have been determined.

\section{CONCLUSION}

All the above mentioned diseases are destructive to the maize production in Nepal or worldwide due to the fact that they occur widespread in maize producing areas. It has been noted that maize diseases reviewed above results in severe economic losses and serves as a potential risk for humans and animals. Therefore, this review can provide sufficient information which will lead to development of management practices, and therefore improve maize production in the affected areas. Also, exploration and proper disease identification will be important to help to understand more about the diseases prior the intervention. Variability within pathogen should be considered for screening and breeding for resistance, or while testing sensitivity of the pathogen towards 
different chemicals. An integrated approach using agronomic, nutritive, or chemical controls should be adopted for an effective disease management. Development of resistant varieties using conventional as well as biotechnological methods will help in controlling these menacing diseases which are still challenges even after several years of their discovery. Studies on epidemiology, diagnosis, yield loss and management of maize diseases (other than host resistance) seem to be quite behind and have to be focused. This review would be helpful to future on maize pathological research works in Nepal.

Table 7. Loss assessment study of important maize diseases in Nepal

\begin{tabular}{|c|c|c|}
\hline Diseases & Loss assessment & References \\
\hline Gray leaf spot & Grain yield loss up to $19 \%$ in local variety & Manadhar and Baidya, 2010 \\
\hline Northern leaf blight & $\begin{array}{l}\text { Reduced plant height ( } 8 \%) \text {, grain yield }(43 \%) \text {, } \\
\text { Biomass }(43 \%) \& 1000 \text { grain weight }(25 \%)\end{array}$ & Duwadi, 1996 \\
\hline Common rust & Losses in grain yield $10-20 \%$ & Manandhar, 1983 \\
\hline Downy mildew & $\begin{array}{l}\text { When the disease incidence was high the } \\
\text { yield loss was estimated up to } 10-20 \%\end{array}$ & Manandhar, 1983 \\
\hline Sclerotial ear rot & $\begin{array}{l}\text { Loss in grain yield up to } 42 \% \text { was found in cv. } \\
\text { Rampur- } 2 \text { at Rampur, Chitwan }\end{array}$ & Manandhar and Poudel, 1997 \\
\hline Fusarium ear rot & Grain yield loss up to $37 \%$ in cv Arun- 4 & Gurung, 1989 \\
\hline & $\begin{array}{l}\text { Under Kakani the yield loss was recorded } 21 \% \text { \& } 6 \\
\% \text { under Rampur }\end{array}$ & Manandhar et al., 1978 \\
\hline Stalk rot complex & $\begin{array}{l}\text { In a farmer's field at Chitwan about } 80 \% \\
\text { grain yield loss was estimated }\end{array}$ & Batsa and Neupane, 1982 \\
\hline
\end{tabular}

\section{ACKNOWLEDGEMENTS}

Thanks to maize Coordinator for continuous support and facilities. Plant Pathologists of NMRP and NARC are also acknowledged for their valuable suggestions.

\section{REFERENCES}

Aday, B. A. (1975). The Philippine program in breeding for resistance to downy mildew of maize. Tropical Agricultural Research Service, 8, 207-219

Agrios, G.N. (2005). Plant pathology . (5 ed.) Burlington, MA.: Elsevier Academic Press.

Asnani, V. L. \& Bhushan, B. (1970). Inheritance study on the brown stripe downy mildew of maize.

Indian Phytopathology, 23, 220-230.
Batsa, B.K. \& Neupane, S.K. (1982). Loss assessment studies on stalk rot of maize. In: Proceedings of the $19^{\text {th }}$ summer crop workshops pp. 99-101 at NMRP, Rampur, Chitwan, Nepal.

Batsa, B.K., Basnet, R., \& Paudel, D.C. (2004). Biological control of banded leaf and sheath blight in maize. P.229. In: Proceedings of the 24 National Summer Crops Research Workshop on maize research and production in Nepal, June 28-30, 2004, Kathmandu, Nepal.

Batsa, B.K., Sharma, R.C., \& Rai, S.N. (2004). Comparative efficacy of cultural, chemical and biological control against banded leaf and sheath blight in maize. P. 232. In: Proceedings of the $24^{\text {th }}$ National Summer Crops Research Workshop on maize research and production in Nepal, June 28-30, 2004, Kathmandu, Nepal. 
Bonde, M.R., Peterson, G.L., Dowler, W.M., \& May, B. (1984). Isozyme analysis to differentiate species of Peronosclerospora causing downy mildews of maize. Phytopathology, 74, 1278-1283.

Butchaiah, K. (1977). Studies on some aspects of banded sclerotial disease of maize. Thesis M.Sc. (Ag.), G.B. Pant University of Agriculture and Technology, Pantanagar. 65 pp.

Butler, E. J. (1907). Some diseases of cereals caused by Sclerospora graminicola. Mem. Dep. Agric., India, BOI. Ser. 2, 1-24.

Chang, S.C. (1969). Genetic studies of resistance to downy mildews in corn by means of chromosomal translocations. Rep. Corn Res. Taiwan 7, 1-6.

CIMMYT Maize Program. (2004). Maize Diseases: A guide for field identification. 4 th edition. Mexico, D.F. : CIMMYT. 2p.

CIMMYT. (1989). Maize Research and Development in Pakistan. CIMMYT, EI Batan, Mexico, $100 \mathrm{pp}$.

Dahal, G., Amatya, P., \& Manadhar, H.K. (1992). Plant diseases in Nepal-country profile. Review of Plant Pathology, 71 (11), 797-807.

De Leon, C. (1984). Maize Diseases, a Guide for Field Identification, 3rd edn. CIMMYT, EI Batan, Mexico.

Desjardins, A.E., Manandhar, G., Plattner, R.D., Maragos, C.M., Shrestha, K., \& McCormick, S.P. (2000). Occurrence of fusarium species and mycotoxins in Nepalese maize and wheat and the effect of traditional processing methods on mycotoxin levels. Journal of Agriculture and Food Chemistry, 48(4), 1377-1383.

Diwakar, M. C., \& Payak, M.M. (1980) Influence of some environmental and host factors on Pythium stalk rot of maize. Indian Phytopathology. 33, 10-15

Diwakar, M.C., \& Payak, M.M. (1975). Germplasm reaction to pythium stalk rot of maize Indian Phytopathology, 28(4), 548-549.

Duwadi, V.R. (1996). Northern leaf blight Helminthosporium turcicum tolerance lines screening of Manakamana -1. In: proceedings of summer crop workshops held in 27-29 ${ }^{\text {th }}$ Feb. 1996, at RARS, Parwanipur Bara, Nepal.

Exconde, O. R. \& Molina, A. B., Jr. (1978). Note: Ridomil (CibaGeigy) a seed-dressing fungicide for the control of Philippine downy mildew. Philipp. 1. Crop Sci. 3, 60-64.

Exconde, O. R. (1983). Virus disease of maize in the Philippines. In: Proc. Int. Maize Virus Disease Cotloqu. Workshop, 2-6 Aug. 1982, Ohio State Univ. (Ed. by D. T. Gordon, J. K. Knoke, L. R. Nault and R. M. Ritter) pp. 203-205, Ohio Agricultural Research and Development Center. Wooster, Ohio.

Exconde, O. R., Raymundo, A. D., \& Soriano, E. L., Jr. (1975). The economics of Duter/Dithane M-45 foliar spray for the control of Philippine corn downy mildew. Philipp. Agric. 59, 237-243.

Exconde. O. R. (1970). Philippine corn downy mildcw. Indian Phytopathology, 23, 275-284

Fisher, D.E., Hooker, A.L., Lim, S.M., \& Smith, D.R. (1976). Leaf infection and yield loss caused by Helminthosporium leaf disease of corn. Phytopathology, 66, 942-944.

Frederiksen, R. A. \& Renfro, B. L. (1977). Global status of maize downy mildew. A. Rev. Phytopathology, 15, 249-275.

Ghimire, S.R., \& Harding, A.H. (1997) . Tilt-250: an effective fungicide to manage head smut Sphacelotheca reiliana (Kuhn) disease. LARC working paper no 97/35, Lumle Agricultural Research Centre, Pokhara, Kaski, Nepal. 
Gregory, L.V., Ayers, J.E., \& Nelson, R.R. (1978) . Predicting yield losses in corn from southern corn leaf blight. Phytopathology, 68, 571-581.

Gurung, G. (1989). Studies on cob rot fungi of maize. In: Proceedings of summer crops workshop held in 17-23 January, 1989 at ARS, Rampur, Chitwan, Nepal.

Gurung, G., Manandhar, K.L., \& Batsa, B.K. (1985). Efficacy of fungicides against head smut of maize. Pp. 95-98. In: Proceedings of 12 Summer Crops Workshop held in Jan 28- Feb 1, 1985 at Rampur, Chitwan, Nepal .

Jingxiong, L. (1991). Maize growing under stress environment in China. In: Proc. 4th Asian Regional Maize Workshop, 21-28 Sept. 1990, Pakistan (Ed. by C. De Leon, G. Granados and M. D. Read) pp. 56-64, Kunming, Nanning.

Kashalappa, A.C.\& Hedge, R.K. (1970). Studies on maize rust (P. sorghi) in Mysore state III: Prevalence and severity on maize varieties and impact on yield. Plant Disease Report, 54(9), 15-20.

Khadka, B.B., \& Shah, S.M. (1967). Preliminary list of plant diseases recorded in Nepal. Nepalese Journal of Agriculture, 2, 47-76.

Koshy, P. K. \& Swarup, G. (1971). Distribution of Heterodera zeae, H. avenae, H. caiani and Anguina tritici in India. Indian Nematol. 4, 106-111.

Lal, B.B. \& Chakravarti, B.P. (1977). Resistance of maize varieties and lines to Physoderma maydis causal organisms of brown spot of maize in Udaipur. Indian Plant Disease Report, 61(2), 1080-1081.

Lal, S. (1975). Brown stripe and sugar -cane downy mildews of maize germplasm evaluation, resistance breeding and chemical control. Trap. Agric. Res. 8, 235-241.

Lal, S., Bhargava, S. K., \& Saxena, S. C. (1980). Management of sugar-cane and brown stripe downy mildews in maize with metalaxyl. Newslell. Int. Working Group Graminicolous Downy Mildews 2.

Manandhar, G. \& Poudel, D.C. (1997). Rhizoctonia ear rot disease and assessment of yield loss due to Rhizoctonia zeae. In: Proceedings of the $20^{\text {th }}$ summer crop workshops pp. 209-215. National Maize Research Program, Rampur, Chitwan, Nepal.

Manandhar, G. (1992). Effect of fungicides to control head smut disease of maize. In: Proceedings of Summer Crops Workshop held in 26-31 January, 1992 at Rampur, Chitwan, Nepal.

Manandhar, G. (1997). 25 years of maize research in Nepal (1972-1997). Nepal Agricultural Research Council, National Maize Research Program, Rampur, Chitwan, Nepal.

Manandhar, G. (2002). Head smut disease of maize in Nepal. Pp. 135- 141. In: N.P. Rajbhandari, J.K. Ransom, K. Adhikari, \& A.F.E. Palmer (Eds). Sustainable maize production systems for Nepal: Proceedings of a maize symposium held in 3-5 December, 2001, NARC and CIMMYT, at Kathmandu, Nepal.

Manandhar, G. (2007). Gray leaf spot a threat to maize production in the hills of Nepal. Quarterly newsletter of Nepal Agricultural Research Council, 14 (4), 4.

Manandhar, G., \& Baidya, S. (2010). Gray leaf spot of maize, a new disease to Nepal and loss assessment. In: Proceedings of the 26th National Summer Crops Workshop held in 3-5 March 2010 at National Maize Research Program, Rampur, Chitwan, Nepal.

Manandhar, G., Baidya, S., Bajracharya, A.R., Ferrara, G.O., and Tiwari, T.P. (2009). Maize gray leaf spot disease - a report presented in review and planning meeting at NARI, 
Khumaltar, Nepal, organized by HMRP-III (NARC/DoA/SDC/CIMMYT) . 14-16 Dec. 2009. Manandhar, G., Baidya, S., Paudel, D.C., \& Burlakoti, R.R. (2007). Evaluation of maize

genotypes for resistant to northern leaf blight disease in Nepal. Pp. 273-275. In: D.B. Gurung,

D.C. Paudel, G. KC, S.R. Upadhyay \& B.B. Pokharel (Eds.). Proceedings of the 25 th National Summer Crops Research Workshop on Maize Research and Production in

Nepal, held in June 21-23, 2007 at Nepal Agriculture Research Institute, NARC, Khumaltar, Lalitpur, Nepal.

Manandhar, G., Desjardins, A.E., Manandhar, H.K., \& Busman, M. (2007). Fusarium graminearum: an important pathogen of maize in Nepal, pathogenic variability and mycotoxins. Pp. 271272. In: D.B. Gurung, D.C. Paudel, G. KC, S.R. Upadhyay \& B.B. Pokharel (Eds.).

Proceedings of the $25^{\text {th }}$ National Summer Crops Research Workshop on Maize

Research and

Production in Nepal, held in June 21 -23, 2007 at Nepal Agriculture

Research Institute, NARC, Khumaltar, Lalitpur, Nepal.

Manandhar, G., Ferrara, G.O., Tiwari, T.P., Baidya, S., Bajracharya, A.S.R., Khadgee, B.R., \& Narro, L. (2011). Response of maize genotypes to gray leaf spot disease (Cercospora zeae-maydis) in the hills of Nepal. Agronomy Journal of Nepal, 2, 93-101.

Manandhar, K.L. \& Shah, S.M. (1972). Screening of corn germplasm against leaf rust diseases under Kakani condition. In: Proceedings of Inter-Asian corn improvement workshop, Bangkok, Thailand.

Manandhar, K.L. (1972). Study on downy mildew disease of maize under Rampur condition. In: Proceedings of Maize seminar held in June 20-22, 1972 held at Department of Agricultural Education and Research Kathmandu, Nepal.

Manandhar, K.L. (1975). Second supplementary list of plant disease in Nepal. FAO Bulletin technical Document No. 97.

Manandhar, K.L. (1976). Preliminary studies of cob tot disease of maize in Nepal. Nepalese Journal of Agriculture, 6, 11.

Manandhar, K.L. (1980). Review on maize diseases investigation from 1975-1980. In: Proceedings of the 8th Summer Crops Workshop held at 25-30 January 1980. National Maize Development Program, Rampur, Chitwan, Nepal.

Manandhar, K.L. (1981). Review of maize disease investigation from 1976-1980. In: Proceedings of 8 summer crop workshop held in 25-30 January 1980 at National Maize Development Program, Rampur, Chitwan, Nepal.

Manandhar, K.L. (1983). Investigation of maize diseases in Nepal - I: Identification and prevalence. Journal of Institute of Agriculture and Animal Science, 4, 45-56.

Manandhar, K.L., \& Gurung, G. (1982). Report on the screening of maize varieties against stalk rot, cob rot and common rust of maize. Pp. 107-114. In: Proceedings of the 9 Summer

Crops Workshops HMG, Ministry of Food, Agriculture and Irrigation, Department of Agriculture held in 25-29 January, 1982 at Parwanipur Agriculture Station, Parwanipur, Bara, Nepal.

MOAD. (2014). Statistical information on Nepalese agriculture 2070/71. Agri-business Promotion and Statistics Division. Ministry of Agriculture Development, Kathmandu, Nepal. 
Mochizuki, N. (1975). Inheritance of host resistance to downy mildew disease of maize. Trap. Agric. Res. 8, 179-193.

NMRP. (2010). Annual Report 2066/67 (2009/10). National Maize Research Program, NARC, Rampur, Chitwan, Nepal.

NMRP. (2011). Annual Report 2067/68 (2010/11). National Maize Research Program, NARC, Rampur, Chitwan, Nepal.

NMRP. (2012). Annual Report 2068/69 (2011/12). National Maize Research Program, NARC, Rampur, Chitwan, Nepal.

NMRP. (2013). Annual Report 2069/70 (2012/13). National Maize Research Program, NARC, Rampur, Chitwan, Nepal.

NMRP. (2014). Annual Report 2070/71 (2013/14). National Maize Research Program, NARC, Rampur, Chitwan, Nepal.

Paudel, D.C., \& Koirala, K.B. (1995). Pathological report on breeding trial and nurseries (19921994). 15p. In: Proceedings of the 18 th Summer Crops Workshop held in 1-2 March 1995 at National Maize Research Program, Rampur, Chitwan, Nepal.

Paudel, D.C., Rijal, T.R., \& Tripathi, N. (2007) . Tolerance and resistance of maize genotypes against southern leaf blight disease. Pp. 256-262. In: D.B. Gurung, D.C. Paudel, G. KC, S.R. Upadhyay

\& B.B. Pokharel (Eds.). Proceedings of the $25^{\text {th }}$ National Summer Crops Research Workshop on Maize Research and Production in Nepal, held in June 21-23, 2007 at Nepal Agriculture Research Institute, NARC, Khumaltar, Lalitpur, Nepal.

Paudel, D.C., Tripathi, N., \& Rijal, T.R. (2007) . Tolerance and resistance of maize genotypes against northern leaf blight disease. Pp. 247-255. In: D.B. Gurung, D.C. Paudel, G. KC, S.R. Upadhyay $\&$ B.B. Pokharel (Eds.). Proceedings of the $25^{\text {th }}$ National Summer Crops Research Workshop on

Maize Research and Production in Nepal, held in June 21-23, 2007 at Nepal Agriculture Research Institute, NARC, Khumaltar, Lalitpur, Nepal.

Payak, M. M. (1980). Management of graminaceous downy mildews - a blueprint. In: Strategies for Control of Graminaceous Downy Mildew (Ed. by R. D. Durbin. R. A. Frederiksen, A. Kelman \& B. L. Renfro) pp. 183-191, The Rockefeller Foundation, New York, USA.

Payak, M. M., \& Renfro, B.L. (1974). A decade of research on maize diseases: impact on production and its international cooperative outreach. In: Current Trends ill Plant Pathology (Ed. by S. P. Rychaudhuri and J. P. Verma) pp. 160--170, Department of Botany, Lucknow University. India.

Payak, M. M., Sharma, R. C., \& Menon, K. (1979). Sorghum downy mildew of maize physiologic specialization and resistant sources. In: Revista De La Facllitad De Agronomica, pp. 177-187

. Universidad Central De Venezuela, Maracay, Venezuela.

Payak, M.M. \& Renfro, B. L. (1967). A new downy mildew disease of maize. Phytopathology, 57, 394-397.

PPD. (2000). Annual report 2055/56 (1998/99). Plant Pathology Division, Nepal Agricultural Research Council, Lalitpur, Nepal.

PPD. (2009). Annual report 2064/65 (2007/08). Plant Pathology Division, Nepal Agricultural Research Council, Lalitpur, Nepal. 
Pradhanang, P.M., \& Ghimire, S.R. (1996). Fungicides management of maize head smut (Sphacelotheca reiliana) by seed treatment. Tropical Agricultural (Trinidad), 73(4), 325328.

Renfro, B. L. (1983). The occurrence and control of downy mildew of maize in Asia. Newlell. Int. Working Group Graminicolous Downy Mildews, 5.

Rijal, T.R. (2012). Makibalima Lagne Mukhya Mukhya Rogharu Tatha Rokthamka Upayaharu (Main diseases of maize and preventive methodologies). Hamro Sampada National Monthly, Kathmandu, Nepal, 4, 48-55.

Rijal, T.R., Paudel, D.C., \& Tripathi, N. (2007) . Screening of maize inbreds/hybrids against banded leaf and sheath blight disease. Pp. 268-270. In: D.B. Gurung, D.C. Paudel, G. KC, S.R. Upadhyay \&

B.B. Pokharel (Eds.). Proceedings of the 25 National Summer Crops Research Workshop on Maize Research and Production in Nepal, held in June 21-23, 2007 at Nepal Agriculture Research Institute, NARC, Khumaltar, Lalitpur, Nepal.

Shah, M. \& Tuladhar, K. L. (1971). Downy mildew diseases of maize in Nepal. Proceedings of 7th Inter Asian Corn Improvement Workshop, Los Banos, Philippines, pp. 88-94, InterAsian Corn Program, Kasetsart University, Bangkok.

Shah, S.M. (1968). Diseases of maize in Nepal. In: Fifth Inter-Asian corn improvement workshop, Department of agriculture and Kesetsart University, Bangkok, Thailand.

Shah, S.M., \& Manandhar, K.L. (1978). A review of corn disease investigation in Nepal (19671977). Pp. 144-159. In: Fourth National Maize Development Workshop, HMG, Ministry of Food, Agriculture and Irrigation, Department of Agriculture held in 9-13 July, 1978 at National Maize Development Program, Rampur Nepal.

Sharma, R. C. \& Payak, M. M. (1979). Resistance to common rust of maize in India. Maize Genetic Cooperation Newsletter 53, 65-66

Sharma, R. C. \& Payak, M. M. (1983). An overview of virus and virus-like diseases of maize in India. In : Proc. Int . Maize VirusDisease Colloqu. Workshop. 2-6 Aug. 1982. Ohio State Univ. (Ed. by D. T. Gordon. J. K. Knoke . L. R. Nault and R. M. Ritter) pp. 186-190. Ohio Agricultural Research and Development Center. Wooster. Ohio.

Sharma, R. C., Payak, M. M., Shankarlingam, S., \& Laxminarayan, C. (1982). A comparison of two methods of estimating yield losses in maize caused by common rust of maize. Indian Phytopathology 35, 18-20.

Sharma, R.C., De leon, Carlos., \& Payak, M.M. (1993). Diseases of maize in South and SouthEast Asia: problems and progress. Crop Protection, 12(6), 414-422.

Singburaudom, N. \& Renfro, B. L. (1982) . Heritability of resistance in maize to sorghum downy mildew (Peronoscferopora sorghi (Weston and Uppal) C. G. Shaw). Crop Prot. I, 323332.

Singh, B.M., \& Sharma, Y.R. (1976). Evaluation of maize germplasm to banded disease and assessment of yield loss. Indian Phytopathology, 19, 129-132.

Singh, I. S. \& Asnani, V. L. (1975). Combining ability for resistance to brown stripe downy mildew in maize. Indian J. Genet. Plant Breed. 35, 128-130.

Tehon, L.R., \& Daniels, E.Y. (1925). Notes on the parasitic fungi of Illinois. Mycologia, 17, 240249. 
Thind, B. S. \& Payak, M. M. (1972). Antibiotics and bleaching powder in the control of bacterial stalk rot of maize. Hindustan Antibiotics Bull. 15, 9-13.

Titatarn, S. (1976). Report on experiments to control corn downy mildew in Thailand. Kasetsart J. 10, 111-115.

Triharso, T. \& Kusdiarti, L. (1976). Recent problems and studies on downy mildew of maize in Indonesia. Kasetsart J. 10, 101-105.

Ullustrup, A.J., (1972). The impacts of the southern corn leaf blight epidemics of 1970/71. Annual Review of Phytopathology, 10, 37-50.

Uppal, B. N. \& Desai, M. K. (1932). Two new hosts of the downy mildew of sorghum in Bombay. Phytopathology, 22, 587-594.

Venugopal, M. N. \& Safeeulla, K. M. (1978). Chemical control of the downy mildews of pearl millet. sorghum and maize. Indian J. Agric. Sci. 48, 537-539.

Xu, M.L., Melchinger, A.E.,\& Lubberstedt, T. (1999). Species specific detection of the maize pathogen Sphacelotheca reiliana and Ustilago maydis by dot hybridization and PCRbased assays. Plant Disease, 83 (4), 390-395.

Zhu, F. C., Chen, Y. T., Zhang, H. F.,\& Tsai, J. H. (1983) . Identification, transmission, host range and epidemiology of maize dwarf mosaic virus in North-western China. In: Proc. Int. Maize Virus Disease Colloqu. Workshop. 2-6 Aug 1982. Ohio State Univ. (Ed. by D. T. Gordon, J. K. Knoke . L. R. Nault and R. M. Ritter). pp. 194-202, Ohio Agricultural Research and Development Center, Wooster. Ohio 